\title{
PERBEDAAN RERATA NILAI FEV1, FVC, DAN FEVR PADA LAKI-LAKI ANTARA PEKERJA KANTORAN DAN PEKERJA YANG TERPAPAR POLUSI
}

\section{THE DIFFERENCE MEAN VALUE OF FEV1, FVC,AND FEVR IN MEN BETWEEN OFFICER AND POLLUTANT EXPOSED WORKERS}

\author{
Sri Wahyu Basuki, Annisa Nurul Lathifah, Ummi Azizah, Manggala \\ Departemen Fisiologi Fakultas Kedokteran Universitas Muhammadiyah Surakarta \\ Korespondensi: dr. Sri Wahyu Basuki, M. Kes. Email: swb191@ums.ac.id
}

\begin{abstract}
ABSTRAK
Polusi udara merupakan salah satu permasalahan yang sering terjadi di perkotaan. Paparan polusi terus menerus dapat menurunkan fungsi paru khususnya pada nilai FEV1, FVC, dan FEVR. Penelitian ini bertujuan mengetahui perbedaan rerata nilai FEV1, FEVR, dan FVC pada laki-laki antara pekerja kantoran dan pekerja yang terpapar polusi. Penelitian ini menggunakan design penelitian observasional analitik dengan pendekatan cross sectional. Penelitian ini dilakukan di Satlantas Kota Surakarta, Kantor BAA dan BAU UMS dan Laboratorium Fisiologi Fakultas Kedokteran UMS. Sampel penelitian yang digunakan adalah laki-laki pekerja kantoran dan pekerja yang terpapar polusi yaitu Supeltas. Besar sampel masing-masing kelompok adalah 30 orang. Teknik pengambilan sampel yang digunakan dalam penelitian ini adalah metode purposive sampling. Perbedaan rerata nilai FEV1, FVC, dan FEVR pada laki-laki antara pekerja kantoran dan pekerja yang terpapar polusi dianalisis dengan uji t tidak berpasangan dan MannWhitney. Hasil penelitian menunjukkan bahwa rerata nilai FEV1 pada pekerja kantoran lebih tinggi daripada pekerja yang terpapar polusi, dengan nilai significancy 0.000. Rerata nilai FVC pada pekerja kantoran lebih tinggi daripada pekerja yang terpapar polusi, dengan nilai significancy 0.000 . Rerata nilai FEVR pada pekerja kantoran lebih tinggi daripada pekerja yang terpapar polusi, dengan nilai significancy 0.004. Dapat disimpulkan bahwa terdapat perbedaan rerata nilai FEV1, FVC, dan FEVR yang bermakna pada laki-laki antara pekerja kantoran dan pekerja yang terpapar polusi $(\mathrm{p}<0.05)$.
\end{abstract}

Kata Kunci: FEV1, FVC, FEVR, Polusi Udara

\begin{abstract}
Air Pollution was one of problem bappened in urban. Continued expose of air pollution could decrease of lung function especially on the FEV1, FVC, and FEVR. The aims of this research are determine differences mean value of FEV1, FVC, and FEVR in men between officer and pollutant exposed workers. This research used analytic observational research design with cross sectional approach. This research was done in Satlantas Surakarta, BAA and BAU offices in UMS and Physiology Laboratory of Medical Faculty UMS. Sample used in this research was officer and pollutant exposed workers such as Supeltas. A large sample of each group consisted 30 respondents. Sampling used in this research was purposive sampling. Independent T test and Mann-Whitney was used to analyze difference mean value of FEV1, FVC, and FEV R in men between officer and pollutant exposed workers. This research showed that mean value of FEV1 in officer higher than pollutant exposed workers, the value of significancy 0.000. The mean value of FVC in officer higher than pollutant exposed workers, the value of significancy 0.000. The mean value of FEVR in officer bigher than pollutant exposed workers, the value of significancy 0.004. It could be conclude that there was significant difference mean value of FEV1, FVC, and FEVR in men between officer and pollutant exposed workers $(p<0.05)$.
\end{abstract}

Keywords: FEV1, FVC, FEVR, Air Pollution 


\section{PENDAHULUAN}

FEV1 (Forced Expiratory Volume in One Second), FEVR ( Force Expiratoy Volume Ratio), FVC (Force Vital Capacity) merupakan indeks sensitif pada perkembangan paru dan berkaitan dengan antropometri dan usia. FVC dan FEV1 merupakan indeks yang sering digunakan untuk menentukan kelainan obstruksi jalan napas, bronkokonstriksi maupun bronkodilatator ${ }^{1}$. Sedang FEVR dapat membantu mengetahui keberhasilan dari efek pemberian bronkodilator ${ }^{2}$. Nilai normal FEV1 $\geq 80 \%$, FEVR $\geq 80 \%$ jika nilai FEVR $<80 \%$ menandakan adanya peningkatan kelainan pernafasan, peradangan sistemik dan kematian, dan FVC normal kirakira kira-kira 4 liter ${ }^{3,4}$. Pemeriksaan dengan spirometer ini penting untuk pengkajian fungsi ventilasi paru secara lebih mendalam ${ }^{5}$.

Pada kenyataannya banyak orang menunjukkan nilai spirometri yang kurang dari normal, misalnya nilai FEVR $<80 \%$ menandakan adanya peningkatan kelainan pernafasan, peradangan sistemik dan kematian ${ }^{3}$. Kelainan obstruksi ditunjukkan oleh penurunan nilai FEV1 dan indeks FEV1/FVC, kelainan restriksi ditunjukkan oleh penurunan nilai FVC sedangkan indeks FEV1/FVC normal, dan kelainan kombinasi ditunjukkan oleh penurunan nilai FVC dan FEV16.

Penurunan nilai FEV1, FEVR, dan FVC dapat disebabkan oleh polusi udara ${ }^{7}$. Polusi udara mempunyai pengaruh besar terhadap kesehatan paru yang dapat menyebabkan proses inflamasi atau peradangan saluran pernafasan ${ }^{8}$.

Penelitian yang dilakukan oleh Ingle et al. (2005) disimpulkan bahwa rerata nilai FEV1 pada polisi lalu lintas sebesar 73\% dan pada kelompok kontrol 118\% ( $\mathrm{p}<0.0001)$. Penelitian lain yang dilakukan oleh Fahimi et al. (2012) didapatkan hasil bahwa rerata FEV1 pada kelompok terpapar polusi sebesar 82,33 \pm 14,20\% dan pada kelompok kontrol didapatkan rerata FEV1 sebesar 90,90 \pm 12,28\% $(\mathrm{p}=0.021)^{9}$.

Berdasarkan penelitian yang dilakukan oleh Shadab, et al. (2014) dinyatakan bahwa terjadi penurunan nilai FEVR $<80 \%$ dan FEV1 60.72 \pm 11.98 pada pekerja limbah dengan kelompok control FEVR > 80\% dan FEV1 $88.50 \pm 18.80$ dengan $(p<0,05)^{9}$. Demikian juga penelitian yang dilakukan oleh ST Ingle et al. (2005) di India, menunjukkan rata-rata nilai FEVR pada polisi lalu lintas sebesar 66\% dan kelompok kontrol 92\% dengan $(\mathrm{p}<0.0001)^{10}$.

Indonesia menduduki rangking 3 tingkat polusi udara tertinggi di dunia dengan emisi kendaraan bermotor menyumbang 70\% polutan. Perkembangan polusi udara di Indonesia setiap tahunnya tercatat mengalami peningkatan sekitar 15\% terutama di kota-kota besar. Sampai detik ini masih banyak masyarakat yang belum sadar pentingnya alat pelindung diri dari polusi udara ${ }^{11}$. Surakarta salah satu kota besar yang rawan polusi. Oleh sebab itu peneliti mengambil tempat penelitian di daerah Surakarta dengan sampel penelitian para pekerja yang terpapar polusi setiap hari terutama polusi udara.

Hipotesis yang akan dibuktikan dalam penelitian ini adalah laki-laki yang bekerja di kantor mempunyai nilai FEV1, FEVR, FVC lebih tinggi dari pada laki-laki yang terpapar polusi setiap hari. 


\section{METODE PENELITIAN}

Jenis penelitian ini adalah penelitian kuantitatif observasional analitik dengan pendekatan cross sectional. Jenis penelitian cross sectional ini, peneliti melakukan pengukuran secara langsung dan dalam waktu tertentu untuk menilai perbedaan nilai FEV1, FEVR, dan FVC pada pekerja kantoran dan pekerja yang terpapar polusi setiap hari.

Penelitian ini dilaksanakan di Fakultas Kedokteran Universitas Muhammadiyah Surakarta dengan waktu penelitian dari bulan November sampai Desember 2014.

Cara pengambilan sampel dalam penelitian ini dengan teknik purposive sampling, besar sampel yang akan digunakan pada penelitian ini sebesar 27 orang untuk setiap kelompoknya. Kriteria inklusi: laki-laki usia produktif berumur 20-59 tahun, bekerja di kantoran atau terpapar polusi setiap hari, IMT normal, dan bersedia mengikuti tes. . Sedangkan kriteria eksklusi: perokok berat, laki-laki yang mempunyai riwayat, didiagnosis dokter, atau sedang menjalani pengobatan penyakit paruparu, mempunyai riwayat, didiagnosis dokter, atau sedang menjalani pengobatan penyakit jantung, dan adanya keterbatasan fisik atau sedang mengalami trauma/cidera.

Data dianalisis dengan uji $T$ tidak berpasangan dan uji Mann Whitney. Sebelumnya dilakukan uji Wilcoxon untuk mengetahui normalitas distribusi data ${ }^{12}$.

\section{HASIL DAN PEMBAHASAN}

Penelitian tentang perbedaan rerata nilai FEV1, FEVR, dan FVC pada laki-laki antara pekerja kantoran dan pekerja yang terpapar polusi setiap hari ini telah dilaksanakan di Laboratorium Fisiologi Fakultas Kedokteran Universitas Muhammadiyah Surakarta pada tanggal 18-20 Januari 2015. Besar sampel 60 orang terdiri dari: 30 pekerja kantoran dan pekerja yang terpapar polusi setiap hari.

Berdasarkan tabel 1 dapat diketahui bahwa distribusi frekuensi pekerja kantoran dan pekerja yang terpapar polusi masing - masing 50\%. Berdasarkan tabel 2 dapat diketahui bahwa mean FVC, FEV1, dan FEVR variabel pekerja kantoran masing-masing lebih besar daripada variabel pekerja yang terpapar polus

Tabel 1. Distribusi Frequensi Sampel Pekerja Kantoran Dan Pekerja Yang Terpapar Polusi Setiap Hari

\begin{tabular}{llc}
\hline \hline Variabel & N & Persentase (\%) \\
\hline Pekerja kantoran & 30 & 50,0 \\
Pekerja yang terpapar polusi & 30 & 50,0 \\
\hline Total & 60 & 100,0 \\
\hline \hline Sumber: data primer & &
\end{tabular}


Tabel 2. Distribusi Nilai Mean

\begin{tabular}{lccc}
\hline \hline \multicolumn{1}{c}{ Variabel } & \multicolumn{3}{c}{ Mean } \\
\hline \hline & FVC & FEV1 & FEVR (\%) \\
\hline Pekerja kantoran & 2908 & 2796 & 97.60 \\
Pekerja yang terpapar polusi & 1987 & 2143 & 93.43 \\
\hline \hline Sumber : data primer & & &
\end{tabular}

Tabel 3. Uji normalitas data

\begin{tabular}{clcc}
\hline \multirow{2}{*}{ Komponen } & \multicolumn{2}{c}{ Shapiro-Wilk } \\
\cline { 3 - 4 } & & $\mathrm{N}$ & $p$ value \\
\hline \multirow{2}{*}{ FVC } & Pekerja kantoran & 30 & 0.944 \\
& Pekerja yang terpapar polusi & 30 & 0.716 \\
\multirow{2}{*}{ FEV1 } & Pekerja kantoran & 30 & 0.001 \\
& Pekerja yang terpapar polusi & 30 & 0.369 \\
& Pekerja kantoran & 30 & 0.094 \\
& Pekerja yang terpapar polusi & 30 & 0.000 \\
\hline \hline
\end{tabular}

Sumber : data primer

Tabel 4. Deskripsi hasil uji t tidak berpasangan dan uji Mann-Whitney

\begin{tabular}{cccc}
\hline \hline Komponen & Uji & $\mathrm{P}$ & Keterangan \\
\hline FVC & Uji t tidak berpasangan & 0,000 & Sangat bermakna \\
FEV1 & uji Mann-Whitney & 0.000 & Sangat bermakna \\
FEVR & uji Mann-Whitney & 0.004 & Bermakna \\
\hline \hline
\end{tabular}

Sumber : data primer

Uji normalitas yang digunakan adalah uji Shapiro-wrilk karena sampel pada penelitian ini masing-masing variabel sebanyak 30 sampel (kurang dari 50 sampel). Berdasarkan tabel diatas, hasil uji normalitas data FVC pekerja kantoran dan pekerja terpapar polusi masing-masing diperoleh nilai $p>0,05$, Oleh karena itu untuk mengetahui perbedaan rata-rata dipakai dari uji t tidak berpasangan ${ }^{13}$.

Adapun hasil uji normalitas data FEV1 pekerja kantoran diperoleh $p<0,05$, sedangkan pekerja terpapar polusi diperoleh nilai $p>0,05$. Oleh karena itu untuk mengetahui perbedaan rata-rata digunakan uji alternatif uji t tidak berpasangan yaitu uji Mann- Whitney karena syarat untuk menggunakan uji t tidak berpasangan tidak terpenuhi ${ }^{13}$.

Adapun hasil uji normalitas data FEVR pekerja kantoran diperoleh $p>0,05$, sedangkan pekerja terpapar polusi diperoleh nilai $p<0,05$. Oleh karena itu untuk mengetahui perbedaan rata-rata digunakan uji alternatif uji $\mathrm{t}$ tidak berpasangan yaitu uji Mann- Whitney karena syarat untuk menggunakan uji t tidak berpasangan tidak terpenuhi ${ }^{13}$.

Berdasarkan tabel di atas, masingmasing variable FVC, FEV1, dan FEVR

Vol. 6 No.1 Februari 2019 
diperoleh nilai $\mathrm{p}<0,05$. Oleh karena nilai $\mathrm{p}$ $<$ 0,05 menunjukkan bahwa adanya perbedaan yang bermakna antara pekerja kantoran dan pekerja terpapar polusi.

Berdasarkan hasil analisis dengan menggunakan uji Mann-Whitney dan T test independent didapatkan nilai $\mathrm{p}<0,05$. Oleh karena nilai $\mathrm{p}<0,05$ menunjukkan bahwa adanya perbedaan yang bermakna rerata FVC, FEV1, dan FEVR antara pekerja kantoran dan pekerja terpapar polusi atau H0 ditolak dan H1 diterima.

Hasil penelitian FEV1, FVC, dan FEVR ini sesuai dengan penelitian yang dilakukan para peneliti, di antaranya:

Igle et al (2005) mengukur hubungan paparan polusi dengan kerusakan fungsi paru pada polisi lalu lintas di kota Jalgaon, India. Terjadi penurunan nilai FEV1 yang bermakna pada kelompok polisi lalu lintas. FEV1 pada polisi lalu lintas sebesar 2.27 L dan kelompok kontrol 2.81 L. Pada penelitian ini diperoleh nilai $\mathrm{p}<0.0001^{9}$.

Penelitian yang dilakukan oleh Fahimi et al. (2012) yang berjudul Asosiasi Antara Polusi Udara dengan IgE Total Serum dan Tes Faal Paru pada Polusi Lalu Lintas didapatkan rerata nilai FEV1 pada kelompok terpapar $82.33 \%$ dan kelompok kontrol $90.90 \%$ dengan nilai $\mathrm{p}=0.015$. Penelitian ini menggunakan pendekatan cross sectional ${ }^{14}$.

Penelitian serupa juga dilakukan oleh Granslo et al. tahun 2012 dengan pendekatan cross sectional. Dia meneliti penduduk Gulen, Norwegia yang hidup di area dekat ledakan tangki minyak $(<6 \mathrm{~km})$ dan kelompok kontrol yang hidup jauh dari area ledakan $(>20 \mathrm{~km})$. Hasil penelitian didapatkan rerata nilai FEV1 pada kelompok dekat ledakan $3273 \mathrm{~mL}$ dan kelompok kontrol sebesar 3437 mL dengan perbedaan rerata - $123 \mathrm{~mL}^{15}$.

Shadab, et al. (2014) meneliti tentang perbedaan FEVR pada pekerja limbah dan kelompok control, didapatkan nilai p < $0.05^{10}$.

Polusi udara merupakan masalah serius daerah perkotaan. Tingkat polusi pada daerah perkotaan selalu meningkat tiap tahun dalam dekade terakhir. Sumber polutan terbanyak pada daerah perkotaan adalah industri dan transportasi. Polutan tersebut dapat masuk ke tubuh manusia bisa dalam bentuk volatile gases seperti ozon, karbon monoksida, benzene, bisa juga dalam bentuk liquid droplets misalnya nitrogen oksida dan asam sulfat, serta dalam bentuk particulate matter seperti hidrokarbon poliaromatik ${ }^{14}$.

Polusi udara berkaitan dengan fungsi paru seseorang. Mekanisme yang mendasarinya yaitu inflamasi dan stress oksidatif. Seseorang yang terpapar polusi terus menerus akan terjadi inflamasi dan stress oksidatif pada tubuh khususnya pada fungsi parunya. Sehingga akan terjadi penurunan fungsi paru yang dapat dilihat sirkulasi darah, lavage bronkoalveolar, stimulasi sputum, dan udara ekspirasinya ${ }^{16}$.

Selain terjadi inflamasi, polusi juga dapat menyebabkan reaksi hiperrespons

Vol. 6 No.1 Februari 2019 
pada saluran bronkial yang dapat meningkatkan respon bronkokontriksi pada saluran napas. Banyak bukti menyebutkan bahwa tingginya level emisi kendaraan bermotor dapat menyebabkan peningkatan allergic respiratory disease ${ }^{17}$.

Terdapat kecenderungan menutupnya saluran napas saat ekspirasi pada penyakit obstruksi saluran napas, akibatnya pasien penyakit obstruksi lebih susah melakukan ekspirasi. Hal ini disebabkan terdapat tekanan ekstra positif dalam dada selama ekspirasi yang menyebabkan terjadinya kolaps saluran napas yang lebih cepat saat ekspirasi. Oleh sebab itu, terjadi penurunan fungsi paru ${ }^{18}$.

Kelebihan penelitian ini dari penelitian yang lain adalah pada sampel yang digunakan. Penelitian ini menggunakan sampel untuk kelompok terpapar polusi yaitu Supeltas, dimana sampel Supeltas khususnya Supeltas kota Surakarta ini belum pernah digunakan untuk menjadi sampel pada penelitianpenelitian yang berkaitan dengan fungsi paru khususnya pada rerata nilai FVC, FEV1, dan FEVR.

Penelitian ini memiliki keterbatasan. Pertama, penelitian ini masih menggunakan design penelitian cross sectional, dimana design ini masih sangat lemah dalam menggambarkan perbedaan rerata nilai variabel pada laki-laki antara pekerja kantoran dan pekerja yang terpapar polusi. Kedua, masih banyak faktor perancu yang belum dapat dikendalikan, seperti: tidak dilakukannya pemeriksaan fisik paru dan pemeriksaan penunjang untuk memastikan tidak adanya kelainan pada paru responden yang dapat mempengaruhi hasil penelitian, masih terdapat responden yang merokok dan belum bisa dilakukan matching perokok antara dua kelompok penelitian, serta tidak dilakukan pengukuran kadar polusi sehingga tidak dapat diketahui seberapa efek yang ditimbulkan.

\section{SIMPULAN DAN SARAN}

Terdapat perbedaan rerata nilai FVC, FEV1, dan FEVR yang bermakna pada laki-laki antara pekerja kantoran dan pekerja yang terpapar polusi

Saran untuk penelitian selanjutnya adalah:

1. Pendidikan dan promosi kesehatan tentang bahaya polusi udara terhadap kesehatan, khususnya kesehatan saluran pernapasan.

2. Perlunya pemakaian alat pelindung diri saat berada di jalan raya atau kawasan berpolusi.

3. Perlu pebentukan taman-taman kota dan penanaman pohon di kawasan perkotaan yang dapat menyerap polusi udara.

4. Untuk penelitian selanjutnya disarankan menggunakan desain penelitian yang lebih kuat dalam menguji adanya hubungan antar variable yang akan diteliti seperti cohort dan dapat dilakukan pada kelompok masyarakat yang lebih luas.

Vol. 6 No.1 Februari 2019 
5. Untuk penelitian lebih lanjut disarankan untuk lebih dapat mengontrol variabel perancu yang dapat mempengaruhi hasil penelitian.

\section{DAFTAR PUSTAKA}

1. Astell-Burt T., Maynard M.J., Lenguerrand E., Whitrow M.J., Molaodi O.R., Harding S., 2013. Effect of Air Pollution and Racism on Ethnic Differences in Respiratory Health among Adolescents Living in an Urban Environment. Journal of Health and Place. 100:171-178. http://dx.doi.org. Diakses tanggal 13 Maret 2013

2. Ozkaya S., Dirican, A., Karanfil, R.C., Bayrak, M.G., Bostanc, O., Ece, F., 2014. The Relationship Between Early Reversibility Test and Maximal Inspiratory Pressure in Patients with Airway Obstruction. International of COPD. 9: 453-6

3. Wan E., Castaldi, P.J., Cho, M.H., Hokanson, J.E., Regan, E.A., Make, B.J., Beaty, T.H., Han, M.K., Curtis, J.L., Curran-Everett, D., Lynch, D.A., DeMeo, D.L., Crapo, J.D., and Silverman, E.K. 2014. Epidemiology, Genetics, and Subtyping of Preserved Ratio Impaired Spirometry (PRISm) in COPDGene. BioMed Central. 15:89-3

4. Schikowski T., Sugiri D., Reimann V., Pesch B., Ranft U., Kramer U., 2008. Contributing of Smoking and Air Pollution Exposure in Urban Areas to Social Differences in Respiratory Health. Journal of BioMed Central Health. 121(9):10341039.http://www.biomedcentral.com/147 1-2458/8/170. Diakses tanggal 24 Mei 2014

5. Sherwood L.L., 2011. Fisiologi Manusia dari Sel ke Sistem. Jakarta: EGC. pp.496-520

6. Linares B., Guizar J.M., Amador N., Garcia A., Miranda V., Perez J.R., Chapella R., 2010. Impact of Air Pollution on Pulmonary Function and Respiratory
Symptom in Children. Longitudinal Repeated-Measure Study. Journal of BMC Pulmonary Centra. 62(10):1-9. http://www.biomedcentral.com. Diakses tanggal 24 Mei 2014

7. Wheeler. B., and Ben-Shlomo Y., 2005. Enviromental Equity, Air Quality, Socioeconomic status, and respiratory health: A Linkage Analysis of Routine Data from The Health Survey for England. Journal Epidemial Community Health. 59:948954. www.jech.com. Diakses pada 24 Mei 2014

8. Vossoughi, M., Schikowski, T., Vierkötter, A., Sugiri, D., Hoffmann, B., Teichert, T., Herder, C., Schulte, T., Luckhaus, C., Raulf-Heimsoth, M., Casjens, S., Brüning, T., and Krämer, U. 2014. Air Pollution and Subclinical Airway Inflammation in the SALIA Cohort Study. BioMed Central. 11:5-1

9. Ingle S.T., Pachpande B.G., Wagh N.D., Patel V.S., Attarde S.B., 2005. Eksposure to Vehicular Pollution and Respiratory Impairment of Traffic Policemen in Jalgaon City, India. Journal of School of Enviromental and Earth Science. 43:656-662. Diakses tanggal 24 Mei 2014

10. Shadab, M., Agrawal, D.K., Aslam, M., Islam N., Ahmad, Z., 2014. Occupational Health Hazards among Sewage Workers: Oxidative Stress and Deranged Lung Functions. Jcdr. 8(4):12.

11. Rachmawati., Masykuri., Sunarto. 2013. Pengaruh Emisi Udara pada Sentra Masyarakat di Desa Karas Kecamatan Sedan Kabupaten Rembang. Jurnal Ilmu Lingkungan. 11: 17

12. Dahlan, M.S., 2011. Statistic Untuk Kedokteran dan Kesehata. Jakarta: Salemba Medika.

13. Dahlan, M.S. 2010. Statistic Untuk Kedokteran dan Kesehata. Jakarta: Salemba Medika.

14. Fahimi M., Dharma B., Fetarayani D., Baskoro A., Soegiarto G., Effendi C., 2012.

Vol. 6 No.1 Februari 2019 
Asosiasi Antara Polusi Udara Dengan IgE Total Serum dan Tes Faal Paru Pada Polisi Lalu Lintas.Jurnal Penyakit Dalam. 13(1):1-9

15. Granslo J., Bratveit M., Hollund B. E., Irgens A., Svanes C., Magerov N., Moen B.E., 2012. Airway Symptoms and Lung Function in the Focal Population After The Oil Tank Explotision in Gulen, Norway. Journal BMC Pulmonary Medicine.12(76)

16. Schikowski T., Schaffner E., Meier F., Phuleria H.C., Vierkotter A., Schindler C., Kriemler S., Zemp E., Kramer U., Bridevaux P.O., Rochat T., Schwartz J., Kunzli N., Probst-Hensch N., 2013. Improved Air Quality and Attenuated Lung
Function Decline: Modification by Obesity in the SALPADIA Cohort. Journal of Enviromental Health Perspectif. 121(9):10341039.

http://dx.doi.org/10.1289/ehp.1206145.

Diakses tanggal 5 Oktober 2014

17. D'Amato G., Cecchi L., D'Amato M., Liccardi G., 2010. Urban Air Pollution and Climate Change as Enviromental Risk Factor of Respiratory Allergy: An Update. Journal Investig Allergol Clin Immunol. 20(2):95-102

18. Guyton A.C. and Hall J.E., 2007. Buku Ajar Fisisologi Kedokteran Edisi 11. Jakarta: EGC. pp. 495-553 